\title{
Sytuacja wyższego szkolnictwa medycznego w latach 1945-1956
}

\author{
Wojciech Giermaziak ${ }^{1}$, Beata Postołowicz ${ }^{2}$ \\ ${ }^{1}$ Główna Biblioteka Lekarska, Warszawa \\ ${ }^{2}$ Główna Biblioteka Lekarska, Oddział w Ciechanowie
}

Adres do korespondencji: Wojciech Giermaziak, Beata Postołowicz, ul. Chocimska 22, 00-791 Warszawa

$\mathrm{K}$ sztatcenie lekarzy w Polsce przed wybuchem II wojny światowej odbywało się na wydziałach lekarskich uniwersytetów (tak jak w całej Europie, poza Związkiem Radzieckim) we Lwowie, Krakowie, Warszawie, Poznaniu i Wilnie ${ }^{1}$. Wieloletnie zamknięcie uniwersyteckich wydziałów lekarskich, utracone Kresy Wschodnie, a wraz z nimi Wilno i Lwów ${ }^{2}$, śmierć wybitnych uczonych i wykładowców, zniszczona baza lokalowa, zrabowane biblioteki, a przede wszystkim brak calkowitego dostępu do światowego nurtu nauki, to ogromne straty poniesione przez polskie nauki medyczne ${ }^{3}$.

W miarę wyzwalania terenów Polskich spod okupacji hitlerowskiej dążono do przywrócenia starych i utworzenia nowych wydziałów lekarskich $^{4}$. Od pierwszych dni po wyzwoleniu przystąpiono do organizacji wyższego szkolnictwa medycznego.

Jako pierwszy w odrodzonej Polsce, w październiku 1944 r., dekretem Polskiego Komitetu Wyzwolenia Narodowego, zostat oficjalnie powotany Uniwersytet Marii Curie-Skłodowskiej w Lublinie. Rok 1944/45 stał się pierwszym rokiem nauczania w Polsce Ludowej na pierwszym, uruchomionym po wyzwoleniu, wydziale lekarskim w kraju. Drugim był Wydział Lekarski Uniwersytetu Warszawskiego, który zainaugurowal swą działalność wczesną wiosną 1945 r. Bezpośrednio po wyzwoleniu Krakowa i Poznania otwarto na nowo Uniwersytet Jagielloński i Uniwersytet Poznański ${ }^{5}$. W „Pamiętnikach lekarzy” pisano: nagle wiadomość, że Kraków wolny, że organizuje się Uniwersytet Jagielloński, a więc wreszcie możliwość dalszych studiów. Na drogach jeszcze niebezpiecznie, ale poszedtem. Siostry zakonne ze szpitala daty na droge duży bochen chleba $i \mathrm{ka-}$ wat stoniny. Wygladato to na średniowieczna wedrówkę żaka do szkót. Wśród zadymki, częściowo „na tebka” samochodem wojskowym, częściowo furmanka i pieszo[...] chtop, który nas wiózt, byt przekonany, że wiezie partyzantów. W tych pierwszych dniach wolności drogi byty prawie puste. Spokojni ludzie woleli nie wydalać się z domów. W drogę udawaty się tylko różnego rodzaju „niespokojne duchy”.

Wśród ruin i zgliszcz na nowo rodziło się w Polsce życie studenckie. Było to jednak niesłychanie trudne ze względu na brak zaplecza lokalowego i kadry nauczającej. Budynki wydziałów lekarskich w Warszawie, Wrocławiu i Gdańsku były zniszczone w ponad $60 \%$. Znacznemu spustoszeniu uległy szpitale, kliniki uniwersyteckie, laboratoria. Zrabowano biblioteki i archiwa. Brakowało książek, skryptów, czytelni studenckich oraz domów akademickich ${ }^{7}$.

Znaczny odsetek studentów stanowili byli żolnierze frontowi. Młodzież, często w wojskowych mundurach, gromadziła się w prowizorycznych salach ćwiczeniowych i wykładowych. Nierzadko uczestniczyła też w odbudowie zaplecza naukowego, z zapałem i ofiarnością odgruzowując i remontując budynki uczelni ${ }^{8}$.

W roku akademickim 1945/46 rozpoczęty swą działalność trzy inne wydziały lekarskie: we Wrocławiu, w Łodzi i Gdańsku . W rezultacie w 1951 r. działało w Polsce dziesięć uczelni medycznych ${ }^{10}$. W tym na bazie dawnych uniwersyteckich wydziałów medycznych: w Warszawie, Krakowie, Poznaniu, Łodzi, Wrocławiu, Lublinie oraz utworzonych od podstaw: w Gdańsku, Katowicach, Szczecinie i Białymstoku ${ }^{11}$. Wobec ogromnych strat osobowych wśród lekarzy problem kształcenia nowych kadr stał się, obok odbudowy bazy, sprawą kluczową ${ }^{12}$. Warto w tym miejscu posłużyć się danymi statystycznymi: w roku akademickim 1946/47 medycynę studiowało 7814 osób, natomiast w 1950/51 już $14805^{13}$. 
Po zakończeniu działań wojennych reaktywowane uczelnie działały na podstawie aktów prawnych obowiązujących do 1939 r. i własnych statutów, dzięki czemu zachowały niezależność. Jednak 1946 r. przyniósł nowe rozwiązanie - szkolnictwo wyższe zostało podporządkowane władzom państwowym, co wiązało się ściśle z ówczesnymi zmianami politycznymi. W październiku $1947 \mathrm{r}$. wydano Dekret o organizacji nauki i szkolnictwa wyższego, który w sposób zasadniczy ograniczył niezależność uczelni, dając tym samym większe kompetencje władzom centralnym ${ }^{14}$. $\mathrm{Z}$ dniem 1 stycznia 1950 r. z uniwersytetów wyłączone zostały wydziały lekarskie, z których utworzono państwowe wyższe szkoły akademickie - akademie medyczne (zwane początkowo lekarskimi). Posłużyło to powstaniu odrębnego pionu wyższego szkolnictwa medycznego w Polsce ${ }^{15}$. Kolejnym krokiem w ograniczaniu niezależności była Ustawa o szkolnictwie wyższym i pracownikach nauki z dnia 15 grudnia 1951 r. ${ }^{16}$. Bezpośredni nadzór nad akademiami obją minister zdrowia, znosząc w ten sposób niemal catkowicie samorządność uczelni, a caly system zarządzania oparto na zasadzie jednoosobowej odpowiedzialności i kierownictwa. Minister posiadał uprawnienia do przekształcania i likwidowania wydziałów i katedr. Powoływał rektorów, dziekanów i prodziekanów na czas nieograniczony ${ }^{17}$. Wprowadzona z przesłanek politycznych ustawa miała w sposób odgórny przyczynić się do budowy socjalistycznej szkoły wyższej ${ }^{18}$. Mimo złego przyjęcia, nie spowodowała jawnego sprzeciwu w środowisku akademickim z uwagi na panujący w kraju reżim. Dopiero 1956 r. przyniósł nowe rozwiązania, kiedy to opracowano i opublikowano nowelizację ustawy z 1951 r. Miało to ścisły związek ze zmianami zachodzącymi po śmierci Stalina, określanymi mianem „odwilży”.

Na wydziały lekarskie zaczęto przyjmować coraz większą liczbę studentów, przekraczającą często możliwości lokalowe. Warunki bytowe były bardzo trudne. Nierzadko zdarzało się, że studiująca młodzież pozbawiona była możliwości zamieszkania $\mathrm{w}$ domu studenckim. Brakowało podręczników ${ }^{19}$. Jednak potrzeby były tak duże, że starano się pokonywać wszelkie trudności. Niektóre specjalności medycyny miały większe braki kadrowe i do tych potrzeb dostosowywano szkolenie personelu. W pierwszej kolejności zwrócono uwagę na konieczność rozwoju opieki nad matką i dzieckiem. Zagadnienie to zostało potraktowane jako bardzo istotne z uwagi na wysoką umieralność niemowląt. Wedtug danych wynosiła ona w 1949 r. 6-9\% w miastach, na wsiach zaś dochodziła do $13 \%$. Natomiast śmiertelność kobiet podczas porodów była $\mathrm{w}$ Polsce cztery razy wyższa niż w innych krajach i sięgała $4 \%$. Zjawisko to wynikało ściśle $\mathrm{z}$ braku odpowiedniej opieki lekarskiej w ciąży i podczas porodu ${ }^{20}$.

\section{Glówne kierunki zmian \\ w systemie ksztalcenia lekarzy}

W pierwszych latach działalności wydziałów lekarskich wszystkich uczelni organizację studiów i tok nauczania oparto na wzorcach przedwojennych. Ze względu na brak podręczników dużą wagę przywiązywano do wykładów i seminariów, w czasie których studenci robili notatki. W ciągu pierwszych dwóch lat prowadzono zajęcia m.in. z anatomii, histologii, fizyki, biologii, chemii, na trzecim roku z patologii, anatomii patologicznej oraz zajęcia kliniczne. Studia trwały pięć lat ${ }^{21}$.

Przelomowy w polskim szkolnictwie okazał się 1949 r., wprowadzający normy i wzory radzieckie. Kształtowanie młodzieży służyć miało wychowaniu komunistycznemu². W 1949 r. w „Stużbie Zdrowia” pisano: Wzorując się na doświadczeniach Zwiazku Radzieckiego dażymy do stworzenia $z$ Akademii Lekarskich takich placówek, które mogtyby wywiąać się $z$ wielkich zadań, jakie stoja obecnie przed nami tak $w$ dziedzinie rozwoju nauk medycznych, jak i dziedzinie intensywnego ksztatcenia owych kadr ${ }^{23}$. Istotą dokonujących się zmian było nasycenie młodzieży treściami ideologicznymi. Z podręczników usunięto poglądy zachodnich naukowców, uniemożliwiając także wszelkie kontakty z nimi. Ośmieszano zasady etyki wykładane na uniwersytetach przed wybuchem wojny ${ }^{24}$.

W szkołach wyższych na wszystkich kierunkach studiów wprowadzono wykłady marksizmu-leninizmu. Działania te miały służyć kształtowaniu postaw socjalistycznych wśród młodzieży i uznaniu przez nią poglądów Marksa, Engelsa, a także Lenina i Stalina za jedynie stuszne kierunki filozofii i podstawę rozwoju wszystkich nauk. Niestety było to naruszenie podstawowej wartości, najważniejszej dla nauki i nauczania - prawdy ${ }^{25}$. Podczas inauguracji roku akademickiego w 1950 r. wiceminister Sztachelski mówil: Na zasadach i nauce marksizmu-leninizmu może jedynie skrystalizować się konsekwentna, gtęboka i twórcza postawa przysztego pracownika stużby zdrowia. Należy w petni $i$ konsekwentnie stosować znakomite osiagnięcia radzieckiej medycyny. Zachęcamy również mtodzież akademicka, aby samodzielnie, indywidualnie $i$ zespotowo pracowata nad gruntownym poznaniem wspótczesnej postępowej i przodujacej nauki radzieckiej ${ }^{26}$.

W szkoleniach brali udział nie tylko studenci, ale również pracownicy naukowi, administracyjni, a także fizyczni. W 1953 r. w rubryce „Z życia akademickiego” pisano: Szkolenie przyczyni się 
niewatpliwie do wzrostu uświadomienia politycznego pracowników Akademii Medycznej i do podniesienia pracy na wyższy poziom ${ }^{27}$.

\section{Rekrutacja na studia}

Pierwsza rekrutacja na wydział lekarski odbyła się w Lublinie w listopadzie 1944 r., a następna w Warszawie wiosną 1945 r. Do komisji zgłaszała się młodzież studiująca medycynę przed wybuchem wojny oraz w czasie okupacji na tajnych uczelniach. Stawiali się także żołnierze Ludowego Wojska Polskiego, Armii Krajowej, byli więźniowie obozów koncentracyjnych, partyzanci. Różnili się wiekiem i przeżyciami z okresu wojny. Podstawą przyjęcia na studia było okazanie indeksu z zaliczeniem danego semestru. Niejednokrotnie zawierucha wojenna spowodowała brak owego dokumentu. Sytuacja taka miała miejsce $\mathrm{w}$ Warszawie, gdzie zniszczeniu uległo około $90 \%$ archiwów szkolnych ${ }^{28}$. W miarę możliwości okazywano zaświadczenia wydawane przez dziekanów lub profesorów. Była to raczej pobieżna weryfikacja. Komisje były przychylne i kwalifikowały warunkowo na dany rok studiów, nakazując odbycie zajęć i zdanie egzaminu z niezaliczonego przedmiotu ${ }^{29}$. W kolejnych latach dobór kandydatów potraktowano znacznie poważniej. W 1945 r. utworzono Państwową Komisję Weryfikacyjno-Kwalifikacyjną, której zadaniem było wydawanie zaświadczeń uprawniających do przyjęcia na studia, oczywiście po wcześniejszym przeanalizowaniu dokumentów kandydata bądź na podstawie przeprowadzonego uproszczonego egzaminu. Kolejne lata to już bardziej wnikliwa selekcja. Oprócz przedłożonego świadectwa dojrzałości, życiorysu, metryki urodzenia, wymagano zaświadczenia o nienagannym zachowaniu, czyli świadectwa moralności. Istotną sprawą był także wynik badania lekarskiego oraz stosunek do służby wojskowej. Także sama forma egzaminu uległa zmianie. Początkowo polegat on na opracowaniu tematu lub streszczeniu referatu. Następnie od kandydatów wymagano szerszej wiedzy z biologii, chemii czy fizyki. W 1948 r. pomyślnie zdany egzamin nie gwarantowat przyjęcia na studia, ale nade wszystko decydowało pochodzenie spoleczne ${ }^{30}$.

Po wojnie w szkolnictwie wyższym dokonały się istotne zmiany pod względem dostępności do studiów medycznych. W pierwszych latach po jej zakończeniu pierwszeństwo przysługiwało inwalidom wojennym, byłym więźniom obozów koncentracyjnych, więźniom politycznym, zasłużonym w odbudowie kraju oraz osobom pochodzenia robotniczo-chłopskiego ${ }^{31}$. Nastąpiła gruntowna przebudowa struktury społecznej młodzieży akademickiej. Przy kwalifikowaniu kandydatów na wyższe studia pierwszeństwo przysługiwało dzieciom przodowników pracy, robotników zatrudnionych przy produkcji przemysłowej oraz członków spółdzielni produkcyjnych ${ }^{32}$. Przeszkody nie stanowif wynik egzaminu, czasem z bardzo niską notą ${ }^{33}$. Egzaminy wstępne wykazywały bardzo niski poziom wiedzy kandydatów oraz brak elementarnej znajomości historii i literatury ${ }^{34}$.

W gorszej sytuacji była młodzież ze środowisk inteligenckich, traktowana przez władze jako „zło konieczne”. Dobrze zdany egzamin wstępny nie gwarantował uzyskania indeksu ${ }^{35}$, z powodu, jak wówczas argumentowano, ograniczonej liczby miejsc. Bardziej istotne były względy polityczne i pochodzenie kandydata. Obojętny stosunek do sytuacji politycznej traktowano jako przejaw wrogości wobec państwa, a odmienność poglądów skutkowała usunięciem z uczelni ${ }^{36}$.

W 1949 r. władze jeszcze bardziej zaostrzyty przekształcanie struktury społecznej młodzieży. Wprowadzono bowiem podział kandydatów na trzy kategorie. Pierwsza to dzieci robotników i chłopów. Druga to inteligencja pracująca, ale zasłużona dla nowego systemu. Trzecia natomiast to element „niepożądany” - inny, którego liczebność według ówczesnych wytycznych nie mogła przekroczyć $15 \%$ ogótu osób zakwalifikowanych ${ }^{37}$.

Wszechobecna propaganda odnosiła się także do kształcenia - w miejsce tradycyjnych studiów uniwersyteckich dostępnych tylko dla wybranej i raczej wąskiej grupy społecznej - elity wywodzącej się z zamożnych rodzin, stworzono uczelnie mające konkretnie ustalone zadania. Chodziło o przygotowanie kadr medycznych w kraju budującym podstawy socjalizmu, którego założeniem było zmniejszenie nierówności społecznych i upowszechnienie wszelkich świadczeń socjalnych oraz umożliwienie zdobycia wykształcenia, do wyższego włącznie, obywatelom niezależnie od klasy społecznej, stanu posiadania czy miejsca zamieszkania. Syntezę owych zmian charakteryzuje wypowiedź przodownika pracy zamieszczona w artykule Stużby Zdrowia: Nauka stużyta dawniej klasom posiadajacym i panującym. Dzieci robotników nie miaty dostępu do wyższej szkoty. Nauka stużyta wytacznie duchowym celom panów i byta cata przesiąknięta duchem kapitalistycznym. Obecnie nauka zmienia swój charakter. Nie odgradza się od ludu, nie trzyma się $z$ dala od niego, lecz stuży ludowi $i$ jego potrzebom. W wyższych szkotach ucza sie nasze dzieci, zdobywaja rzetelna wiedze, aby oddać ją na stużbę ludowi, na stużbę budownictwa socjalistycznego. My, spod ziemi, z goracych kuźni, $z$ szerokich hal fabrycznych $w$ petni liczymy na nasza mtodzież, która wyszedtszy z ludu, wróci do niego, by dlań pracować38.

Na szkolnictwie wyższym spoczywała odpowiedzialność za wykształcenie nie tylko dobrego 
fachowca, samodzielnie myślącego pracownika i społecznika. Chodziło również o ksztattowanie oblicza ideowego i światopoglądu przyszłego lekarza. Władze komunistyczne były świadome, że przekonanie do nowej ideologii lekarzy Polski przedwrześniowej będzie bardzo trudne. Postanowiono zatem skupić się na socjalistycznym wychowaniu młodzieży, której łatwiej było zaszczepić nowe wartości ${ }^{39}$. Nasilenie tego procesu nastąpiło w momencie objęcia władzy w państwie przez Polską Zjednoczoną Partię Robotniczą (PZPR) w 1948 r. i pogłębienie procesu stalinizacji Polski, trwającego do czasu tzw. odwilży, której pierwsze symptomy można było dostrzec w 1954 r. ${ }^{40}$.

Na inauguracjach roku akademickiego nie gościli już przedstawiciele zachodnich ambasad, zapraszano natomiast prezydenta, premiera, ministrów oświaty i zdrowia, przedstawicieli PZPR, a także przodowników pracy i chłopów. Atmosferę oddaje sprawozdanie z inauguracji roku akademickiego, jakie pojawiło się w „Stużbie Zdrowia”: Dom Hutnika, $w$ którym zgromadzili sie licznie studenci i przybyli na uroczystość goście przyozdobiono czerwienia, na tle której zawieszono portret Ludwika Waryńskiego, wielkiego bojownika o wolność proletariatu. Nad portretem umieszczono transparent $z$ napisem: Nauka w stużbie mas pracujacych $[. . .]^{41}$. Głos zabierali również sami studenci: Z ogromna radościa witamy dziś $w$ tak uroczystej dla nas chwili Prezydenta Bolestawa Bieruta $w$ gronie robotników, studentów i naukowców. Przyjmujemy jednocześnie to wielkie wyróżnienie, jakie spotkato naszą mata garstkę spośród mtodzieży catej Polski, jako zobowiąanie do stania się przodującym jej oddziatem. Nazakończenie przemówienia obywatel Krauze wznióst okrzyk na część wodza międzynarodowego obozu pokoju i postępu Generalissimusa Stalina. Okrzyk pochwycili wszyscy zebrani. Orkiestra odegrata Międzynarodówkę $e^{42}$.

W 1949 r. na łamach Służby Zdrowia informowano społeczeństwo o poprawiającej się sytuacji nauki oraz szkolnictwa wyższego: Nasze wielkie braki $w$ dziedzinie kadr, zwtaszcza lekarskich sa zaspakajane z jednej strony przez planowe $i$ konsekwentnie przystosowane do potrzeb ośrodków robotniczych rozsiedlenie czynnych już lekarzy, $z$ drugiej zaś przez intensywne szkolenie nowych fachowców w naszych wydziatach lekarskich. Wszystkie te uczelnie otwarte sa dla mtodzieży robotniczo-chtopskiej ${ }^{43}$.

\section{Socjalistyczna dyscyplina studiów}

W latach 1949-1951 zauważono, że okoto $33 \%$ studentów nie kończyło studiów, a liczba osób które wprawdzie ukończyły studia, ale nie zdały egzaminów końcowych, a co za tym idzie nie uzyskały dyplomów, zaczęła wzrastać. Wobec takiego stany rzeczy na wszystkich uczelniach wprowadzono socjalistyczną dyscyplinę studiów. Obowiązkowa stała się obecność na wszystkich wykładach, ćwiczeniach i seminariach oraz udział w pracach społecznych i ,prasówkach”, w trakcie których omawiano aktualną sytuację polityczną. Kilkukrotna nieobecność w ciągu semestru na tych zajęciach skutkowała usunięciem ze studiów ${ }^{44}$. Podkreślano, że: należy napiętnować $i$ wyeliminować wszystkich nierobów i wszystkie elementy niespoteczne, dlatego też z jednej strony nalegano na to, ażeby nie pozwalać na repetowanie roku $i z$ drugiej strony - nie udzielać ulgowych terminów dla uzyskania dyplomów tym, którzy $z$ wtasnej winy tych terminów nie dotrzymalit ${ }^{4}$.

Socjalistyczną dyscyplinę studiów nadzorowały władze uczelni, przy czynnej pomocy organizacji młodzieżowej, jaką był Związek Młodzieży Polskiej (ZMP). Był on politycznie, organizacyjnie i ideowo podległy PZPR, utworzony w 1948 r., mający na celu podporządkowanie ruchu młodzieżowego (na wzór radzieckiego Komsomołu) jednej partii. ZMP propagowat idee stalinowskie, a więc rozbudowę przemysłu, kolektywizację wsi i współzawodnictwo pracy. Zło kojarzone było z przeszłością, natomiast nowoczesność zła nie znała. Owe cele organizacja zamierzała osiągnąć poprzez środki wychowawcze, m.in. promowanie współzawodnictwa pra$\mathrm{cy}^{46}$. Młodzież podejmowała zobowiązania, a prasa drukowała propagandowe artykuły. Jeden z nich zawieral następującą informację: Stuchacze pierwszego roku studiów Akademii Lekarskiej $w$ Poznaniu wystapili $z$ inicjatywa wspótzawodnictwa $w$ uzyskaniu najlepszych wyników $w$ nauce. Wspótzawodnictwo, prowadzone przez zespoty samopomocy naukowej, obejmuje m.in. terminowe ukończenie studiów, podniesienie poziomu nauki w oparciu o zdobycze wiedzy radzieckiej oraz prace nad wytworzeniem $w$ pracownikach stujby zdrowia socjalistycznego stosunku do wykonywanych zadań ${ }^{47}$. Okazji do podjęcia zobowiązań było wiele, chociażby Zlot Młodych Przodowników Budowniczych Polski Ludowej czy Tydzień Światowej Federacji Młodzieży. Studenci deklarowali pomoc przy budowie Centralnego Parku Kultury, odgruzowywaniu stolicy, a nawet udział w zespołach artystycznych dających przedstawienia w hotelach robotniczych ${ }^{48}$. Zdarzało się, że zobowiązania dotyczyły oszczędzania odczynników chemicznych, gazu i szkła laboratoryjnego w pracowniach chemicznych ${ }^{49}$.

Działania te miały stużyć realizacji Planu 6-letniego, do którego przystąpili również studenci medycyny w dowód tączności z klasą 
robotniczo-chłopską. Głównym założeniem było wyszkolenie dużej liczby młodych kadr i nieustanne mobilizowanie ich do osiągania coraz lepszych wyników w nauce. Nacisk kładziono również na zacieśnianie kontaktów i współpracy podstawowej organizacji partyjnej i organizacji studenckich z kierownictwem uczelni ${ }^{50}$.

\section{Nakazy pracy}

Zjawisko nakazów pracy pojawiło się w polityce nowych władz w 1950 r., co wiązało się z koniecznością podjęcia zobowiązań Planu 6-letniego na lata 1950-1955. Chodziło o kierowanie młodych medyków do pracy na tereny głównie wiejskie, gdzie braki były największe. W marcu 1950 r. opublikowano Ustawę o planowym zatrudnianiu absolwentów średnich szkół zawodowych oraz szkół wyższych ${ }^{51}$, która określiła zasady zatrudniania absolwentów. W tym też roku po raz pierwszy powolano przy akademiach medycznych komisje przydziatu pracy dla absolwentów ${ }^{52}$. Do zadań komisji należało wydawanie młodym lekarzom nakazów pracy na okres nie dłuższy niż trzy lata ${ }^{53}$. Były to zazwyczaj placówki lecznictwa zamkniętego (szpitale, sanatoria, zakłady psychiatryczne), gdzie młodzi zdobywali praktykę. Zakład pracy, do którego absolwent był skierowany, zobowiązany był zwrócić mu koszty podróży oraz zapewnić mieszkanie. Po przystąpieniu do pracy przysługiwała zaliczka na poczet uposażenia, w wysokości $100 \%$ miesięcznego wynagrodzenia ${ }^{54}$. Formą zachęty było terminowe ukończenie studiów, co miało gwarantować możliwość większego wyboru miejscowości i zakładów spośród przewidzianych planem zatrudnienia. Ci, którzy nie zdali wszystkich egzaminów w terminie, otrzymywali stanowisko felczera ${ }^{55}$. Niestety praca komisji budzita niejednokrotnie zastrzeżenia ${ }^{56}$. Studenci określali ją jako biurokratyczną machinę decydującą bezdusznie o ich losach ${ }^{57}$.

Same nakazy były traktowane przez młodych medyków jako zło konieczne. Bardzo często zdarzało się, że studenci odkładali w czasie termin obrony pracy dyplomowej, aby chociaż na chwilę oddalić ich realizację. Jako negatywny przykład stawiano absolwentów przedwojennych, którzy nie uzyskawszy dyplomów, pracowali w stużbie zdrowia: rentgenolog z Krakowa - Golinski, absolwent z roku 1924, który posiada wtasny zaktad, doskonale zarabia i nie podlega przepisom o wtaściwym rozmieszczeniu lekarzy, gdyż... nie jest lekarzem ${ }^{58}$. W myśl ustawy młodzież kierowano do ośrodków wiejskich znacznie oddalonych od dużych miast. Na etaty kliniczne mogli liczyć tylko „wybrani”, przodownicy nauki, co stanowić miało zachętę do efektywnej i twórczej nauki $^{59}$.

\section{Warunki bytowe mlodzieży}

W pierwszych powojennych latach warunki bytowe określano jako bardzo trudne. Sami studenci mówili, że żyło się i jadło byle gdzie i byle jak. Podstawą wyżywienia były dorsze, marmolada buraczana, ziemniaki i chleb ${ }^{60}$. Sytuacja lokalowa, szczególnie w Warszawie, była bardzo uciążliwa. Z powodu braku własnych miejsc noclegowych młodzież kwaterowała w salach klinik, internatach urządzanych w szpitalach czy na zasadzie „użyczania strychu”. Takie rozstrzygnięcia przynosity obopólną korzyść. Studenci w zamian za dach nad głową i darmowe wyżywienie pomagali przy opiece nad pacjentami i w innych szpitalnych obowiąz$\mathrm{kach}^{61}$. Na przestrzeni kolejnych miesięcy sytuacja mieszkaniowa ulegała stopniowej poprawie. Sprawami bytowymi zajęty się organizacje samopomocowe - Bratnia Pomoc. Sprawą pierwszoplanową były kwestie mieszkaniowe, żywnościowe, zaopatrzeniowe (wyposażenie młodzieży w odzież pochodzącą z UNRR- $y^{62}$ ), jak i te pomniejsze, choćby kulturalno-oświatowe ${ }^{63}$.

W 1946 r. pierwszeństwo przy przyjęciu do domów akademickich przysługiwało inwalidom wojennym, więźniom obozów, uczestnikom walk o wolność i niepodległość Polski, młodzieży pochodzącej z warstw chłopskich, robotniczych oraz inteligencji pracującej ${ }^{64}$. Pokoje wyposażone były $\mathrm{w}$ prosty i niezbędny sprzęt, niekoniecznie kompletny. Bywało, że zamiast łóżka proponowano studentom materace, z uwagi na to, że tych drugich było więcej. Niekiedy w akademiku organizowano pralnię, własną kuchnię, a nawet pracownię szewską ${ }^{65}$.

W omawianym okresie młodzież poszukiwata źródel zarobkowania. Studentów zatrudniano w charakterze korepetytorów, higienistów szkolnych, w pogotowiach opiekuńczych dla dzieci, choć zdarzało się, że znajdowali pracę również na uczelniach w charakterze pomocników asystentów ${ }^{66}$.

Innym źródłem dochodów były stypendia. $\mathrm{Na}$ mocy ustawy z dania 7 marca 1950 r. wprowadzono państwowe stypendia dla młodzieży szkół wyższych. Kryterium przyznania było pochodzenie spoteczne, postępy w nauce oraz ideowa postawa osoby ubiegającej się. Zachętą do bycia zdyscyplinowanym studentem były jednorazowe premie stypendialne wypłacane młodzieży wyróżniającej się w nauce. Inną formą mobilizacji były stypendia dyplomowe. Ich odbiorcami byli studenci, którzy ukończyli tok nauki, ale z przyczyn losowych czy finansowych nie zdali egzaminu dyplomowego. Przez dofinansowanie absolwentów państwo zobowiązało się umożliwić im uzyskanie dyplomu. Oczywiście warunkiem było terminowe ukończenie studiów ${ }^{67}$. 


\section{Podsumowanie}

Po śmierci Stalina w 1953 r. zaczęła zmieniać się sytuacja polityczna w Związku Radzieckim i państwach satelickich, w tym w Polsce. Prawdziwym przełomem okazał się XX zjazd Komunistycznej Partii Związku Radzieckiego (KPZR), szczególny wstrząs wywołat tajny referat wygłoszony przez Chruszczowa w lutym 1956 r. Poddat on druzgocącej ocenie Stalina i system przez niego stosowany. Sytuacja ta wzmogła napięcia w PZPR. Przettumaczenie tajnego referatu na język polski i jego ogłoszenie, przyspieszyło liberalne poglądy wśród członków PZPR, a w społeczeństwie wzbudziło nadzieje na humanizację systemu i stopniowe odzyskiwanie utraconych swobód ${ }^{68}$.

W 1956 r. PZPR przestała rozstrzygać w sprawach wewnętrznych uczelni, wiele osób wystąpiło z jej szeregów. Działacze partyjni stali się niewidoczni, niektórzy nawet radykalnie zmienili poglądy. Młodzież zaczęła jawnie ignorować zajęcia z marksizmu-leninizmu i ekonomii politycznej, co w konsekwencji doprowadziło do ich zniesienia. Wprowadzono natomiast wykłady z zakresu filozofii, logiki i historii medycyny. Studenci domagali się odideologizowania studiów i prawa do tworzenia apolitycznych organizacji młodzieżowych. W trakcie obrad rektorów i dziekanów pojawily się krytyczne uwagi pod adresem resortu i władz partyjnych. Potępiono narzucanie dokonań nauki radzieckiej jako obiektywnej i jedynie słusznej. Mówiono o braku kontaktu z medycyną zachodnią i odcięciu dopływu najnowszej literatury ${ }^{69}$.

We wrześniu 1956 r. uchylono ustawę o socjalistycznej dyscyplinie studiów. W swej koncepcji miała ona powiększyć liczebnie dobrze wyszkolony personel medyczny, tymczasem $w$ praktyce okazało się, że obowiązek uczestnictwa na wszystkich zajęciach nie gwarantowal lepszych wyników na egzaminach. Zwrócono uwagę, że istotnym elementem jest jakość kształcenia przyszłych lekarzy ${ }^{70}$.

Rekrutacja na studia w omawianym okresie stanowiła także element polityki ówczesnych władz, która w swym zamyśle prowadziła do podporządkowania wszystkich grup społecznych i ograniczenia wolności osobistej obywateli. W roku akademickim 1956/57 przedtużono do 6 lat studia lekarskie z uwagi na, jak twierdzono, stabe przygotowanie praktyczne studentów.

Liberalizacja trwała krótko. W 1957 r. ograniczono pracownikom naukowym wyjazdy na Zachód. Na uczelniach zaczęto tworzyć upolitycznione organizacje młodzieżowe, m.in. Związek Młodzieży Socjalistycznej (ZMS), w którym kierownictwo objęli byli działacze ZMP. Powróciły też wykłady z przedmiotów ideologicznych ${ }^{71}$.

Otrzymano: 2018.04.16 - Zaakceptowano: 2018.05.15

\section{Przypisy}

1. Wiśniewski: Lekarskie drogi. Czasy reżimu Stalina, Warszawa, 221. 2. Słabek H.: O spolecznej historii Polski 1945-1989, Warszawa 2009, 61.

3. Wysocki A.: Lekarze polscy w czasie II wojny światowej [w:] Dzieje medycyny w Polsce. Opracowania i szkice, t. 3 , red. W. Noszczyk, Warszawa 2015, 641.

4. Historia medycyny, pod red. T. Brzezińskiego, Warszawa 1995, 423.

5. Dziesięciolecie medycyny w Polsce Ludowej 1944-1954, L. Hirszfeld (red.) i in., Warszawa 1956, 506.

6. Pamiętniki lekarzy, Warszawa 1968,725 .

7. Studia na wydziałach lekarskich [w:] Dzieje medycyny..., op. cit. 241.

8. Paciorek M.: Rekrutacja studentów na wydziały lekarskie w drugiej połowie lat 40. i 50. XX w. - elementem polityki władz państwowych wobec inteligencji, Medycyna Nowożytna 2012, z. 1/2, 219.

9. Dziesięciolecie medycyny, op. cit.

10. Ibidem, s. 60.

11. Murkowski M., Koronkiewicz A., Cieślukowski Z.: Zasoby opieki zdrowotnej w Polsce w okresie 50-lecia 1945 - 1955 i perspektywa ich wykorzystania w latach 2002-2005, Zdrowie Publiczne 2000, 6, 222.

12. Wiśniewski Z., Lekarskie drogi..., op. cit.

13. Rocznik statystyczny ochrony zdrowia 1945-1967, Warszawa 1969 , 515 .

14. Noszczyk W.: Przepisy prawne dotyczące szkolnictwa wyższego oraz stopni i tytułów naukowych [w:] Dzieje medycyny..., op. cit., 233.

15. Pacho A., op. cit. 133

16. Dz.U. 1952, nr 6 poz. 38.

17. Noszczyk W.: Przepisy prawne..., op. cit. 234.

18. Słabczyński J.: Zarząd szkołą wyższą w Polsce Ludowej, Warszawa $1968,31$.

19. Pacho A.: Organizacja służby zdrowia w PRL, Warszawa 1972, 172.

20. Kozłowska U., Bulsa M.: Przemiany polskiej służby zdrowia w latach 1950-1960. Zagadnienia ochrony zdrowia matki i dziecka (najważniejsze problemy), Hygeia Public Health 2015, nr 1, 244-246.

21. Noszczyk W.: Studia na wydziałach..., op. cit., 245.

22. Paciorek M.: Rekrutacja studentów..., op. cit., 221.

23. Titkow W.: Reorganizacja wyższego szkolnictwa medycznego, „Służba Zdrowia"1949, nr 15, 2

24. Noszczyk W.: Sytuacja polityczno gospodarcza [w:] Dzieje medycyny..., op. cit. 245.

25. Nauczanie etyki w uczelniach medycznych, red. J. Suchorzewska i M. Olejniczaka, Gdańsk 2007, 11.

26. Inauguracja roku akademickiego w Lubelskiej AM, Stużba Zdrowia $1950, \mathrm{nr} 42,2$.

27. AM w Lublinie zakończyła kurs szkolenia ideologicznego, Stużba Zdrowia 1953, nr 25, 2 .

28. Paciorek M.: Studenci wydziałów lekarskich w Polsce w latach 1944/1945-1948/1949. Ksztattowanie i rozwój środowiska, Warszawa 2016, 166.

29. Noszczyk W.: Sytuacja polityczno ..., op. cit., 243.

30. Paciorek M.: Studenci wydziałów..., op. cit., 167

31. Noszczyk W.: Sytuacja polityczno..., op. cit.

32. Dzieje uczelni medycznych w Warszawie w latach 1944-1960, Warszawa 1968, s.70.

33. Paciorek M.: Studenci wydziałów..., op. cit., 182.

34. Ibidem.

35. Paciorek M.: Rekrutacja studentów..., op. cit., 231.

36. Ibidem.

37. Herczyński R.: Spętana nauka, opozycja intelektualna w Polsce 19451970, Warszawa 2008, 47

38. Uroczysta inauguracja roku akademickiego, „Służba Zdrowia”1949, nr 18, 1.

39. Kochanowicz J.: ZMP w terenie. Stalinowska próba modernizacji opornej rzeczywistości, Warszawa 2000, 27.

40. Paciorek M.: Rekrutacja studentów..., 220-222.

41. Uroczysta inauguracja..., op. cit.

42. Ibidem.

43. 16000 Studentów studiuje medycynę, stomatologie i farmację, Służba Zdrowia 1949, nr 18, 2.

44. Noszczyk W.: Studia na wydziałach..., op. cit., 247.

45. Wdrożenie dyscypliny pracy i opieki nad studentami na wszystkich wydziałach Akademii Medycznych, Stużba Zdrowia 1951, nr 10, 1.

46. Kochanowicz J.: ZMP w terenie. Stalinowska próba modernizacji opornej rzeczywistości, Warszawa 2000, 15-17.

47. Poznańscy medycy wzywają do współzawodnictwa w nauce, Służba Zdrowia 1950, nr 8, 1.

48. Studenci warszawskiej AM wybrali delegatów na Zlot, Służba Zdrowia 1952, nr 27, 1

49. Studenci A.M. podejmują zobowiązania, Stużba Zdrowia 1951, nr 14, 6 . 
50. Nauka i wychowanie spoteczne młodzieży w AM w Poznaniu, Stużba Zdrowia 1953, nr 21, 2.

51. Ustawa o planowym zatrudnianiu absolwentów średnich szkół zawodowych oraz szkół wyższych, Dz.U. 1950, nr 10, poz. 106.

52. Zarządzenie Ministra Zdrowia z dnia 7 czerwca 1950 r. w sprawie powoływania przy akademiach medycznych oraz szkołach dla średniego personelu służby zdrowia komisji przydziału pracy dla absolwentów na rok 1950, Dz.U. MZ 1950, nr 12, poz. 104

53. Paciorek M.: O wychowaniu „nowego typu lekarza” na przełomie lat 40 i 50. XX w., Medycyna Nowożytna" 2014, z. 2, 145.

54. Planowe kierowanie do pracy absolwentów Akademii Medycznych, Służba Zdrowia 1950, nr 27, 3 .

55. Absolwenci AM w Szczecinie otrzymali przydziały pracy, Służba Zdrowia 1955, nr 17, 3 .

56. Działek S.: Więcej troski o absolwentów w komisjach przydziału pracy, Służba Zdrowia 1953, $\mathrm{nr}$ 13, 3 .

57. Tatoń J.: Głosy studentów na marginesie artykułu prof. Z. Majewskiej, Stużba Zdrowia 1953, nr 6, 2

58. Wzmożenie dyscypliny pracy i opieki nad studentami na wszystkich wydziałach Akademii Medycznych, Służba Zdrowia 1955, nr 5, 2.

59. Paciorek M.: O wychowaniu..., op. cit., 144-145.

60. Onisk A., Jankowski W.: Pierwsi absolwenci Akademii Lekarskiej w Gdańsku i ich osiagnięcia zawodowe, Gdańsk 1998, 5.
61. Paciorek M.: Studenci wydziałów..., op. cit., 264.

62. UNRRA, Organizacja Narodów Zjednoczonych do Spraw Pomocy i Odbudowy, międzynarodowa organizacja utworzona 9 listopada1943 r. w Waszyngtonie z inicjatywy USA, Wielkiej Brytanii, ZSRR i Chin, majaca na celu udzielenie natychmiastowej pomocy krajom alianckim najbardziej dotkniętym wojną; pomoc obejmowała zarówno artykuły pierwszej potrzeby (żywność, leki, surowce), jak i podstawowe urządzenia [w:] Popularna Encyklopedia Powszechna, t. 18, Kraków 1997, 317.

63. Ibidem.

64. Ibidem, 265.

65. Ibidem, 268 .

66. Ibidem.

67. Paciorek M.: Dyscyplina pracy i nauki na przykładzie studentów polskich wydziałów lekarskich na przełomie lat 40. i 50., Medycyna Nowożytna 2013, z. 2, 173-174.

68. Roszkowski W.: Historia Polski 1914-2015, Warszawa 2017, 258-260.

69. Noszczyk W.: Studia na wydziałach..., op. cit., 249.

70. M. Paciorek, Dyscyplina pracy..., op. cit., s.191 - 192.

71. Noszczyk, Studia na wydziałach..., op. cit. 